\title{
Pentecostal ecumenical impulses: Past and present challenges
}

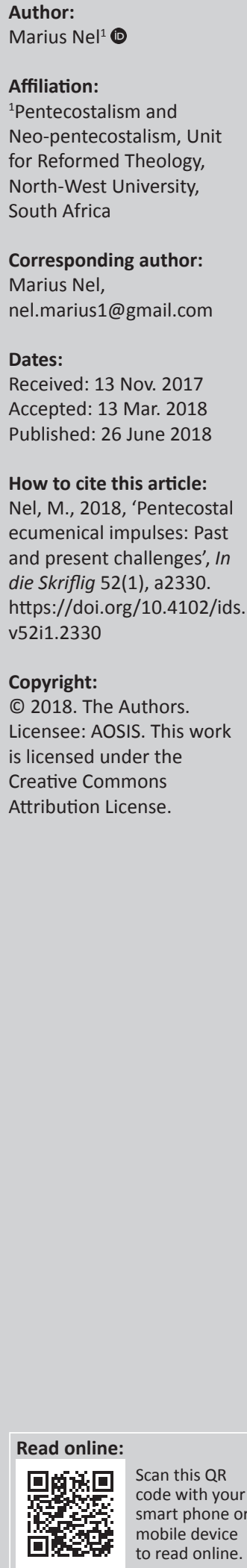

Several leaders in the early Pentecostal movement interpreted the outpouring of the Spirit at the Azusa Street Mission and other places as a sign that the Spirit would now unite Christians across the borders of denominations in a new Pentecost that concurs with the events of Acts 2 which led to the formation of the Early Christian Church. They did not actively pursue ecumenism, but expected it as a natural and spontaneous result of the Spirit's work, carried by their primitivist and restorationist impulses. Instead of the other churches appreciating and accepting Pentecostal experiences as interventions by the Spirit, most main-line churches alienated and rejected Pentecostals as a heretical sect. Within one generation, Pentecostalists entered denominationalism and by the 1940s, in an upward social mobility surge, aligned themselves with some evangelicals with a biblicist-literalist hermeneutics. Today Pentecostalism has accepted that Spirit baptism did not bring the expected unity of the Christian church and entered into formal ecumenical relations with several international ecumenical bodies and para-church organisations. It is argued that an ecumenical impulse need to originate on grass roots level. Ecumenism will only succeed when the local assembly and its members become involved. This can be done, for example by building ecumenical relations with historical churches that experience a charismatic renewal, neo-Pentecostalist groups and African Indigenous Churches, especially those with a historical connection with Pentecostalism, and motivating assemblies to cooperate with assemblies of their denomination in instituting a regular worship service in a common language where members may fellowship together. The aim of such contacts would not primarily be to realise organisational unity, but mutual understanding and communication leading to cooperation and trust.

\section{Introduction}

The classical Pentecostal movement represents a wide diversity of denominations and churches most of which trace their origins to the Azusa Street revival of 1906 and its emphasis on glossolalia and other charismata which, in some way, relates to Spirit baptism. ${ }^{1}$ Any attempt at generalising the Pentecostal movement is confounded by its diversity in doctrine, practice and spirituality. In this article, an early ecumenical impulse as well as major historical and current ecumenical efforts are described. The aim is to motivate an on-going ecumenical interest as well as to provide guidelines for the movement to further effective ecumenical endeavours, because its focus on the Spirit ensures that the ideal of spiritual unity was never fully set aside by Pentecostals.

\section{Early ecumenical impulse}

Hollenweger (1997:34) remarks that Pentecostalism started with a self-perception that it was an ecumenical renewal movement, because the experience of Spirit baptism represented a renewal of the Day of Pentecost that established the Early Church that functioned in unity across boundaries. Robeck (1991:1) insists that even 'a cursory reading of the earliest Pentecostal publications is sufficient to validate [the] claim'. Azusa Street was, from the start, an interracial and multidenominational revival movement (Burgess 2011:236) rather than a church. Early Pentecostals were optimistic that the outpouring of the Spirit would lead to church unity, because the Spirit would unite Christians across the borders of denominations in a new Pentecost. They were open for cooperation with other Christians. Seymour and other leaders of the Early Movement believed that their experience of Spirit baptism implied the restoration of what happened on the day of Pentecost in Acts 2, including the restoration of the church as the sign that the end of the age has come. ${ }^{2}$ The way they interpreted the Bible had led many supporters of the Holiness Movement to

1.While scholars recognise the Pentecostal tradition's multiple points of origin within and without the United States of America, the events at Azusa Street are most frequently associated with its birth. Some points of origin include a number of locations outside the USA in which Pentecostalism is indigenous rather than the result of missionary expansion from the USA (Stephenson 2009:1).

2.At Azusa Street, the leader of the revival, William Seymour (1870-1922), stressed not only the importance of Christian unity, but also racial reconciliation and cross-cultural ministry (Dodson 2011:52). 
expect that the Spirit would be poured out again like the day of Pentecost and they prepared and prayed for it. When this happened on 09 April 1906 in Los Angeles (Burgess 2011:237), their optimism was followed by confrontation and confusion as Jacobsen (2010:4), Kärkkäinen (2000:14) and Robeck (1986:65) illustrate. ${ }^{3}$ Instead of renewing and uniting existing historical denominations, the new movement and its experience were rejected, reviled and booed as a sect and became alienated from main-line churches.

The new movement justified its existence as a restoration of the heritage of the earliest church that was lost when the persecuted church was accepted as state church in the 4th century. ${ }^{4}$ It named itself as Apostolic Faith, Latter Rain, Christian Union and 'Pentecostal' to demonstrate its concept of being in continuity with the early tradition. At the same time, it justified its existence as the eschatological anticipation of a forthcoming universal ecumenical restoration of all of God's people (Dayton 1987:23; Vondey 2014:274). Speaking in tongues was interpreted as the reversal of the confusion of the one language of all the earth at Babel (Gn 11:7-9) that will bring unity to all Christians. This is a fulfilment of Moses' sigh that all God's people would be prophets (Nm 11:29) and the realisation that Christians would be able to proclaim the gospel to people of all languages to the ends of the earth. ${ }^{5}$ Now that people speak the languages of the Spirit, they would at last understand each other and the church would unite.

For instance, Charles Fox Parham (1902:61), founder of Bethel Bible College that was closed in 1901, and the new Bible School in 1905, which Seymour also attended (Burger \& Nel 2008:17), prophesises in 1902 that, to live as a Pentecostal, was to live as an 'apostle of unity'. Even though, William Seymour (1906:2), leader of the Azusa Street Mission called the Apostolic Faith Gospel Mission, wrote in 1906 that the Pentecostal movement stands for the restoration of the faith and for 'Christian Unity everywhere'. This leads to Green's assertion (2011:16) that, as first-generation Pentecostals yearned physically to enter the apostolic world to breathe its

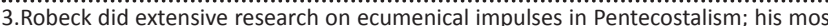
important contributions are Robeck and Sandidge (1990), and Robeck (1993; 1994; 1995; 1996; 1997).

4.Compare Wacker (1984:353-375) for a discussion and explanation of the Pentecostal view of history. Blumhofer (1993:12) describes the restorationist claim as 'the impulse to restore the primitive or original order of things as revealed in the Scripture, free from the accretions of church history and tradition'. The diversity from the start of the movement is acknowledged. In Anderson's words (2005:153), 'Pentecostalism has had many beginnings, and there are many "Pentecostalisms"', making it possible to speak of 'movements' that were identified with the unifying
and empowering work of the Spirit in Acts 2 . The outpouring of the Spirit, argues Clifton (2012:577), is manifest in the bewildering gift of 'many tongues', as symbolic Clifton (2012:577), is manifest in the bewildering gift of 'many tongues', as symbolic
of a new unity among people of every nation and the fulfilling of the prophecy of of a new unity among people of every nation and the fulfilling of the prophecy of theology of baptism in the Spirit thus constituted the ecclesiology of Pentecostal movements, and framed and directed their praxis (Macchia 2006:155). Pentecostals share an interpretative historical model of the ideal Early Church that gradually degenerated from the 3rd century when it lost its emphasis on Spirit baptism and the praxis of charismata which, eventually, lead to its existence as a state church.

5.Early Pentecostals believed that they had received the ability to speak specific languages, that is, not glossolalia but xenolalia [known foreign tongues] (Burgess 2011:233). They identified themselves as the restoration of the Acts 2 church and considered their experience of speaking in languages as a supernatural impartation of power that allows the gifted person, equipped in this way, with an unknown existing language to evangelise the world without the difficulty of laboriously learning the languages needed to reach the lost (Synan 1997:4). The anticipated proclamation in different tongues, however, soon disappointed the earliest proclamation in different tongues, however, soon disappointed the earliest
missionaries on mission fields when nobody understood their 'Spirit tongues', and missionaries on mission fields when nobody understood their 'Spirit ton
early Pentecostals had to look again at what the New Testament teaches. air, feel its life, see its signs and wonders with their own eyes, this impulse continued to shape the Pentecostal imagination even if now tempered somewhat by decades of socioeconomic 'lift' and theological developments.

Vondey (2014:274) asserts that in theological terms, the ecumenical impulse among early Pentecostals reflected 'a particular ecclesiological ethos' characterised by their reluctance to refer to themselves as a church or denomination in contradistinction to historical or traditional denominations that they caricatured as formalist, institutionalised and ritualised. They evaluated the existence of many main-line denominations as a sign of their obsession with doctrinal correctness (orthodoxy), hiding the fact (as Pentecostals perceived it) that they were spiritually dead (Conway 1917:5). Pentecostals' spirituality, informed by the experience of Spirit baptism, generated an explicitly ecumenical vision, writes Clifton (2012:578). Just like the ecumenical movement that also originated at the beginning of the 20th century, Pentecostals looked back on the preceding centuries of competitive Christianity and envisioned a different future. ${ }^{6}$ They saw themselves not as a new church, but as a movement of the Spirit to carry the fresh wind of the Spirit into existing churches with the aim to restore Christianity to its 1st-century shape (Vondey 2014:275).

They expected Christian Unity to follow the outpouring of the Spirit that occurred throughout the world, as in South Africa, in response to the Azusa Street revival. One never reads that Pentecostals thought that ecumenism was something that Pentecostals should pursue. However, they expected that it would follow as a natural result of the Spirit's work. The expectation was carried by several elements. The first is the primitivist and restorationist impulse, the result of Pentecostals' interpretation of their experiences in continuity with the Early Church (Nel 2017:2) as a form of criticism of main-line churches' apparent lack of charismatic practices. ${ }^{7}$ Their critical attitude contributed to their alienation from existing churches when they appreciated their spiritual experiences as unique interventions by the Spirit in contradistinction to the older churches that they perceived as to be caught up in a deadly web of tradition and doctrine (Faupel 1996:46) - a sense of superiority that prohibited the possibility of any cooperation with existing churches. ${ }^{8}$

6.Compare, for example Lederle (2010:5) who identifies the ecumenical movement and Pentecostalism as two 'Spirit movements' of the 20th century and argues that each has been deeply concerned with the work of the Holy Spirit in the world. He adds that, while he appreciates their respective initiatives and growth, both would benefit if they would cooperate, because while they arose simultaneously, they did so in isolation from each other.

7.Pentecostals' criticism of traditional churches had originated in the movements which had provided the first adherents of classical Pentecostalism, the holiness, divine healing and Zionist movements that used the primitivistic matrix which divine healing and Zionist movements that used the primitivistic matrix which a modern context and to a significant extent justified the reason for their existence as a critique on existing traditions (Dayton 1987:40-41; cf. Nel 2016 for a full as a critique
discussion).

8.The ecumenical thrust of Pentecostalism was understood as transcending forma doctrine and structure. It consists of a non-doctrinal unity in the Spirit, a grassroots relational unity, which understood the body as an organism and not as an organisation (Clifton 2012:579). Lancaster (1926) writes that

THE APOSTOLIC FAITH MISSION is NOT another CHURCH [sic]. It is the Assembly of those who, throughout Australasia, are seeking to prove that our Blessed Lord is just the same as He was when He commissioned the disciples to 'go into all the world'. (p. 10) 
In a brief time, Pentecostals experienced rejection and persecution at the hands of established churches. Their charismatic experiences became the butt of criticism rejected by traditional denominations as 'sensual', 'devilish' and 'deluded', and ministers of these churches who had experienced Spirit baptism were removed from the ministry (Nichol 1966:70). For instance, the World Christian Fundamentals Association distanced itself in 1928 from the Pentecostal movement (Frodsham 1971:7). In reaction to the widespread rejection and ridicule, even in the secular press, Pentecostals separated themselves further in ecumenical exclusivity, viewing their rejection by the churches as a sure sign of their chosenness as the Spirit's vehicle for returning the nations to God before the end times dawn.

Another factor that impacted on the early ecumenical impulse among Pentecostals, is the occurrence of internal divisions and fractures, reflecting the many disagreements on practice, doctrine, church politics, elections of leaders and personalities. Classical Pentecostals ('first-wave' Pentecostals) divided into Holiness Pentecostals, 'Baptistic' Pentecostals and Oneness Pentecostals (Daniels 1999:238-239; Lewis 2016:4). For instance, controversies rocked the Azusa Street leadership about racial issues, Oneness-Trinitarian viewpoints and sanctification as a second crisis. At the same time the movement experienced the need to structure and formalise the different communities that, characterised by leadership ambitions as well as differences in theological emphasis and practice, eventually led to the establishment of different denominations, changing the Pentecostal movement into the 'business' of 'church' and mission. ${ }^{9}$ Lastly the ecumenical ideal of unity did not realise, because it did not take into account the fact that human communities need organisation and institution to function, and that even creeds and religious traditions serve a functional purpose (Clifton 2012:580). The establishment of diverse and competitive organisational structures deprived Pentecostals of ecumenical endeavours, even with one another. ${ }^{10}$

The Early Movement grew at a phenomenal rate, keeping its leaders busy and convincing them that cooperation with other traditions that expresses animosity toward Pentecostals would be counterproductive. Without realising it, Pentecostalism lost its initial rejection of traditional ecclesiastical patterns and organisational forms, and entered the world of denominationalism (Vondey 2011:114). The 'revival movement' had changed into 'churches' with 'assemblies', vying with one another for new members

\footnotetext{
9.Clifton (2012:577) argues convincingly that the problem was not institution per se, but rather the particular shape and culture of the institutional developments that occurred. Pentecostalism established structures that facilitated church leadership that focused on the local church with shared efforts in education and mission. It was a personal and cultural movement of the Spirit that did not deify or sacralise its institutional structures, enabling it to emerge in multiple forms - a fact that goes to the heart of its globalisation. Its pragmatic spirituality enabled it to change its shape as indigenous grassroots fellowships of Spirit-filled people.

10.Poloma (1989:94) describes what she calls the 'institutional dilemmas' that resulted from the bureaucratisation and institutionalisation of the Assemblies of God (USA). She observes that there is a sociological tendency for religious groups to move from a prophetic to a priestly stance and that it implies that the free flow to move from a prophetic to a priestly stance and that it implies that the free flow of charismata eventually ends in a lifeless routinisation. For instance, the Pentecostal movement can demonstrate the impact of the routinisation.
}

reflecting an ecclesiology of competition (Vondey 2010:155). By the 1940s, the American Pentecostal movement formed an alliance with evangelicals in the National Association of Evangelicals, ${ }^{11}$ aligning themselves to a biblicist-literalist hermeneutics that further disqualified them from any ecumenical dialogue with other traditions. Pentecostal leaders abstained from cooperation with the emerging ecumenical movement while their institutional structures calcified, killing any ecumenical impulse (Vondey 2014:278). Pentecostalism was now marked by three factors: denominationalisation, evangelicalisation and upward social mobility (Dodson 2011:53). Pentecostal denominational structures formed and the outward focus toward the renewal of the church and Society turned more inward toward maintenance and establishment of Pentecostal agencies, institutions and networks.

\section{A new ecumenical impulse}

Pentecostals kept their focus on the Spirit and never lost the hope that the ideal of spiritual unity might still realise, as Martin (2002:170) notes. Their theology of Spirit baptism acted as a potent symbol of spiritual unity. ${ }^{12}$ Despite its bewildering division and diversity, Pentecostalism remains an identifiable global movement of churches that share a transformative and unifying experience of the Spirit.

The international ecumenical movement developed since 1910 in the wake of the First World War with the establishment of the International Missionary Council and Foreign Missionary Council of North America. That developed into the National Councils of Churches and eventually the World Council of Churches (WCC). At that stage, however, the original ecumenical impulse in the new Pentecostal movement was being frustrated, and Pentecostals organised worldwide cooperation only among themselves.

Two influential ecumenical figures, the Brit, Donald Gee (1891-1966) and South African, David J. du Plessis (1905-1987) emerged as leading forces in accommodating the ecumenical impulse among Pentecostals. International Pentecostalism did not originally initiate any ecumenical contacts. Gee and Du Plessis organised the first worldwide conferences where Gee was elected as editor of Pentecost, the Pentecostal World Fellowship's periodical (Hollenweger 2000:391-392). At a meeting of the General Council of the Assemblies of God in America in 1937, which was attended by Pentecostal leaders

\footnotetext{
11.Evangelicalism is defined as the theological system that resulted from the synthesis of churches forming the National Association of Evangelicals in 1942 with its main concern being the communication of the gospel to the whole world, calling individuals to personal faith in Christ (Lewis 2001:3; Railey \& Aker 2007:50). The net result of this crosspollination, argues Dodson (2011:53), was an experientially diminished form of Pentecostalism. Because many evangelicals were uncomfortable with tongues and prophecy, they exerted pressure on Pentecostals to take a more cautious approach to the use of these gifts. Now the experiential, theophanic dimensions of the tradition were giving way to a more Word-centred piety. Pentecostalism moved from the margins toward the mainstream (via association with evangelicals) and it was accompanied by a socio-economic repositioning with with evangelicals) and it was acch mans middle class (Dodson 2011:53)

12.Different forms of unity exist and should be distinguished from one another as Venter (2008:341-355) argues: hierarchical, confessional, denominational, ecumenical, sectional, structural, mystic, invisible, sacramental, charismatic, dogmatic, unity-within-diversity and Spirit unity.
} 
from various countries, the need was expressed to organise a World Pentecostal Conference. The Second World War intervened and the meeting planned for 1940 in London had to be cancelled. The destruction of the war contributed to the inception of the first World Conference of Pentecostal Churches where Pentecostal churches, worldwide, planned to cooperate closely to meet the spiritual and physical needs in Europe. The name was later changed to the Pentecostal World Fellowship - a global cooperative body without any legislative authority (Slosser 1977:115). Its first conference was held in 1947 in Zurich, Switzerland with Leonard Steiner as the first chairperson. The delegates expressed the conviction that the Holy Spirit desired a closer communion between Pentecostal churches (Burger \& Nel 2008:179; cf. Venter's conceptions of 'Spirit unity' 2008:348). The second conference was held in 1949 in Paris, France and it concentrated on spiritual communion, exchange of ideas, prayer and Bible study among participants as well as the themes of inspired preaching, the Lord's Supper and public meetings. A conference has since been held approximately every three years. The major Pentecostal denominations in South Africa are participating in the activities of the Pentecostal World Fellowship and I.S. Burger of the Apostolic Faith Mission of South Africa (AFM) of South Africa served as its vice-chairperson until 2016 (Mahlobo 2016:19)

Gee and Du Plessis were also responsible for interpreting the Pentecostal movement to interested outsiders, including to the WCC, the Roman Catholic Church and Protestant organisations that Pentecostal denominations avoided contact with. The international Pentecostal movement overcame its resistance over time and supported the initiatives established by Gee and Du Plessis. Du Plessis was general secretary of the AFM from 1936 to 1947. The church supported his ecumenical endeavours. When Du Plessis moved to the USA in 1947, he joined the Assemblies of God who eventually defrocked him in 1962, because they did not agree with his understanding of ecumenism, and especially, his contact with the Roman Catholic Church that they perceived as 'the scarlet woman' of Revelation (Clifton 2012:585). He was reinstated in 1980 (Robinson 1992:143155). This led to the initial disqualification of Du Plessis and other ecumenical leaders within Pentecostalism to speak on behalf of a diverse and diffused movement (Clifton 2012:585).

National fellowships of churches were established - also in South Africa. In South Africa, the racially defined white and language-determined Afrikaans-speaking denominations did not ally with the South African Council of Churches (SACC) due to the outspokenness of the SACC on various political issues and its criticism of the racial policies of the Nationalist government. The unified AFM joined the SACC only in 2003, even though the AFM'S vice-president at that time, Frank Chikane, formerly played a leading role in the SACC while he was the leader of the black and later the uniting AFM.

After the Second World War, many Pentecostal churches simultaneously experienced dissatisfaction with models of leadership and instituted several institutional changes in response to the anti-intellectual, exclusivist and sectarian mind-set of early Pentecostals. ${ }^{13}$ Many Pentecostal churches formed an alliance with the evangelicals, and since 1961, several national Pentecostal councils and organisations also joined the WCC. ${ }^{14}$

Since the 1960s, glossolalia started to occurr in some historical denominations - leading to the charismatic movement ('second-wave' Pentecostals) that refocused the vision of the ecumenical discussion of Pentecostal witness (cf. Hocken 1987; McDonnell 1972; 1978; 1980 for a reappraisal of the ecumenical potential and dimension of Pentecostal practice and doctrine within the charismatic movement). ${ }^{15}$ Their endeavours led to the first official ecumenical dialogue of the worldwide Pentecostal movement, with the Roman Catholic Church (Kärkkäinen 2007:3). ${ }^{16}$

Since the 1970s, worldwide Pentecostalism was influenced by the development of Pentecostal scholarship. Earlier Pentecostal contributions to ecumenical dialogue, even in the early dialogue between the Roman Catholics and Pentecostals, was hampered at times by a lack of theological depth and Pentecostals' prejudice against what they perceived to be intellectual ecumenism without any practical results, measured in missiological terms. The pioneer in Pentecostal scholarship was Walter Hollenweger. ${ }^{17}$ Discussions at the Pentecostal World Conference in 1970 led to the establishment of the Society for Pentecostal Studies in the USA, opening new ecumenical opportunities for intellectual cooperation with nonpentecostals. The Society encouraged its members since the 1980s to cooperate with ecumenical bodies.

A last development that shaped Pentecostal ecumenical involvement is the reshaping of the movement in terms of the establishment of highly successful neo-Pentecostalist megachurches ('third-wave' Pentecostals). In several respects

13.It can be argued that this mind-set was a plausible reaction to the rejection and humiliation experienced at the hand of existing churches that led to economic and emotional discrimination against members of Pentecostal churches. However times had changed and younger leaders imagined a new role for Pentecostalism in society.

14.For a long period Pentecostals perceived that they were side-tracked in the WCC leading in 2000 to the formation of a Joint Consultative Group in the WCC to accommodate Pentecostal contributions, especially to unity, mission, evangelism accommodate Pentecostal contributions,
and spirituality (Van Beek 2006:81-92)

15.Through this renewal movement, Pentecostals experienced unprecedented support for the practices of tongues, prophecy and other charisms from many Christians in mainline denominations and this newfound acceptance from many in the mainline denominations went a long way toward restoring the ecumenically outward focus of the Pentecostal tradition present at Azusa Street (Dodson 2011:53). Clifton (2012:584) calls the unity that the charismatic renewal of the 1970 s and 1980s created the effect of the supernatural capacity of the Spirit to affect this sort of unity, grounded in emphases on Spirit-baptism and experiential spirituality and realising early Pentecostals' expectation of unity. The renewal spirituality and realising early Pentecostals expectation of unity. The renewal transcended the constraints of Pentecostal denominations and created unique relationships between people with very different church commitments. This was not an ecumenical movement organised by denominational hierarchies or by way of formal theological conversations but, instead, by the Spirit's bringing people
together in worship'.

16.Roman Catholic dialogue with the Pentecostals should be evaluated in the light of the Second Vatican Council. Compare Pope Francis (2013) who states:

Commitment to ecumenism responds to the prayer of the Lord Jesus that 'they may all be one' (Jn 17:21). The credibility of the Christian message would be much greater if Christians could overcome their divisions and the Church could much greater if Christians could overcome their divisions and the Church could realise 'the full Chrs of catholicity proper to her in those of ther children who, though joined her'. (p. 182)

17.Noel (2010:68) refers to Hollenweger as the 'dean of Pentecostal studies'. 
it differs sharply from classical Pentecostal denominations (e.g. in their notions of prophecy, prophets and apostles and their emphasis on prosperity) and influenced these denominations to a certain extent (in a liturgical and theological manner) (cf. Stephenson 2013:85). ${ }^{18}$

\section{Future of ecumenism among Pentecostals: Some proposals for the local church}

To date, international Pentecostalism has entered successfully into ecumenical relations with the Roman Catholic Church, the WCC, the World Communion of Reformed Churches (WCRC), the Lutheran World Federation (LWF), the Baptist World Alliance (BWA), the Synodal Committee for InterOrthodox and Inter-Christian Affairs of the Ecumenical Patriarchate of Constantinople, the Mennonite World Conference, the Salvation Army (Vondey 2014:281-282) and the Global Christian Forum. They also formed an alliance with para-church organisations such as Women's Aglow Fellowship (WAF) and Full Gospel Business Men's Fellowship International (FGBMFI) (Albrecht 2017a:18). The original ecumenical impulse has stayed alive on macro level.

South African Pentecostal denominations like the Assemblies of God, Pentecostal Holiness Church, AFM and Full Gospel Church participate in the activities of The Evangelical Alliance of SA (TEASA), Empowered21 Southern Africa subregion with Frank Chikane as co-chairperson and a member of its Global Council, and the SACC of which Chikane serves as one of the vice-presidents (Mahlobo 2014:116; 2016:19).

In South African Pentecostal denominations, ecumenical endeavours are left to the initiative of the national office bearers of the different denominations, implying that each time new office bearers are elected the process has to start from scratch. What is needed is that denominational headquarters establish ecumenical offices with staff responsible for managing mutual ecumenical affairs to counteract the current lack of continuity.

The most important condition for ecumenism to succeed, however, is on local grass roots level where ecumenical contacts depend on sociocultural engagements of pastors and interested members with other churches and church bodies. ${ }^{19}$ It is probably true to asserts that the majority of Pentecostal leaders at the level of local assemblies do not participate in any form of ecumenical involvement (Vondey 2001:348) except to support actions of aid groups that care for

18.Lederle (2010:204) controversially writes that large portions of "third-wave Pentecostalism such as the 'word-of-faith' or 'positive confession' theology should be actively embraced, because it indicates the trajectory of where Pentecostalism is headed as a theological movement. While I do not agree, it should be admitted that 'third-wave' Pentecostalism is influencing the 'first-wave' denominations and reaching the global South (Kalu 2008:255-266), especially through its effective utilisation of mass and social media because the the West to the Two-Thirds world of the South and East (Plüss 2003:16).

19.This is true for all denominations as well as for independent congregations without any denominational affiliation. Leadership among Pentecostals is not limited to the standard established roles (e.g. pastor, elder, deacon, worship team). Spontaneous leadership may emerge through nearly any member of the congregation as any one 'moved by the Holy Spirit' takes action (Albrecht 2017a:1). old age homes, orphanages or hospitals and ministers' fraternals. It is argued here that ecumenism will only succeed when the local assembly and its members become involved, serving as a precondition for a successful ecumenical impulse among Pentecostals. ${ }^{20}$ Moreover, that will only happen when denominational leadership structures prioritise the issue of ecumenism on the agendas of their synod meetings and establish ecumenical offices that constantly motivate and equip local assemblies to invest in ecumenical contacts something that does not seem to be feature in the agenda of major South African Pentecostal denominations.

Local assemblies' lack of interest in ecumenical endeavours can be attributed to leaders without an ecumenical conscience, $^{21}$ a lack of opportunity, ignorance about the importance and skills needed for ecumenical dialogue, fear and (a historically based) resentment toward other traditions based on rejection of any institutional form of religion as well as an ecclesiology, which is exclusivist and sectarian (Albrecht 2017b:4) based on the perception that Pentecostals' experience of being Spirit-filled, makes them superior to other traditions. The Pentecostal apprehension is then rooted in stereotypes concerning other forms of Christianity that are untested. Because they are unsure of the authenticity of another's authenticity as followers of Christ, Pentecostals (and it may be true of some other traditions as well) then avoid fellowship. Hinson (1993:1-14) agrees that discerning the Spirit's actions in the contemporary faith community is essential to any meaningful ecumenical relationship and adds that Christians, attempting to relate ecumenically, need to have the gift of discernment and wisdom to distinguish the work of the Spirit in the history of the other. At the same time, Pentecostals must realise that others may perceive and experience God quite differently, resulting in a different type of Christian spirituality. ${ }^{22}$ As Macchia (2003) writes:

We might even discover that every church tradition is gifted in unique ways toward the edification of the church catholic,

20.1 do not agree with Clifton's (2012:576) assertion that even if the ecumenical spirit of early Pentecostalism had been maintained, its grassroots, bottom-up ecclesiology would have prevented substantial involvement in the formal, creedal and institutional processes that have characterised the ecumenical movement to date. If Pentecostal ecclesiology is determined by the Spirit's activity in the lives of members and the worship service, one would expect that ecumenical endeavours would occur because of the Spirit's uniting function.

21.Rance (2009:4) describes ecumenical leadership as apostolic in the sense that it displays the ability to discern the voice of the Spirit and to yield to Spirit (1) empowerment (both by prioritising the integration of the Spirit's call and his gifts of natural and by prioritising the integration
supernatural empowerment.

22.Plüss (2003) quotes from a letter by Hollenweger that states:

I think it makes ecumenical dialogue easier if Pentecostals no longer argue that their spirituality is entirely and solely spirituality of the Spirit and the other churches' spirituality is only traditional rites and outward form. The Spirit uses outward forms and fills them with life, if we let him (or her) do so and if we do not make of it culturally determined forms of dogma. (p. 18)

Dodson (2011:51) asserts, for instance that the practices of tongues and prophecy no longer hold a prominent place in most Pentecostals' regular worship services. These practices are embraced mostly in the context of extraordinary revival environments, small group settings or individual, private prayer, leading to a changing self-identity. Dodson argues that the apparent declining interest in prophecy and speaking in Dodson argues that the apparent declining interest in prophecy and speaking in tongues in Pentecostal churches may be misleading, because it does not adequately acknowledge ecumenical developments in the broader Pentecostal theology of charismatic gifts which now highly values less extraordinary charisms. Pentecostals see the work of the Spirit in non-Pentecostals as a shift in thinking that may have potential to reorient the larger tradition toward its ecumenical, interracial and intercultural foundations present at the Azusa Street revival (1906-1909). Pentecostal spirituality itself is facing continuous changes. 
discovering perhaps that gifts of grace are not even confined to the universal church. (p. 6)

Ecumenical endeavours require the humility to realise that there is not one single church or world communion today that can comprehend and include all the different ways in which the Holy Spirit calls people to proclaim the gospel and live their faith so that their lives are meaningful to their neighbours, communities, and sisters and brothers in the ecumenical fellowship of churches (Robra 2016:253).

Ecumenism is the desire to understand and affirm the other's experience of God. What is needed, first of all, is the Spiritdriven desire to keep up ecumenical relations with people of other traditions. In the words of Robeck (2004:308-309), we need to discover that we are one people regardless of our pet denominational names and hobbies. We need finally to admit that together we are the people of God, the body of Christ, followers of Jesus Christ who together form the universal church of Christ. Then we will finally confess that many of our reasons for separate existences or different denominations are as artificial as our national demographic differences. Moreover, the body of Christ is the fellowship of Jesus Christ or the Spirit (Brunner 1953):

[...] where fellowship or koinonia signifies a common participation, a togetherness, a community life. The faithful are bound to each other through their common sharing in Christ and in the Holy Ghost, but that which they have in common is precisely no 'thing', no 'it', but a 'he', Christ and His Holy Spirit. (pp. 10-11)

In terms of intra-denominational ecumenical endeavours, South Africa poses several unique challenges for Pentecostal ecumenical endeavours. For instance, the AFM, which is the largest Pentecostal denomination with 1.4 million members, started as a multiracial church, but soon fell into the groove of other churches in South Africa and segregated along racial lines. The church united in 2006 across racial barriers, but it can be argued with justice that relations between the different races within the church, to an important extent, have not been established on the level of local assemblies (cf. Lapoorta s.a.:174). The same is probably true of other South African Pentecostal churches where white people prevailed historically as the 'mother church' contra the 'mission (or racially defined) churches'.

The obstacle of language hampers South African Pentecostal churches. White people and mixed race people are cooperating in white Afrikaans-speaking assemblies, but their language excludes black people that form the majority of their members. What is needed is that local churches of the same denomination should reach out and cooperate with each other in the area by instituting a regular worship service at a central place in a language understandable by all (English) where the denomination's members across boundaries may worship in fellowship together. This would not exclude Afrikaans-speaking churches or churches using indigenous languages to continue with services in their own language, but should create the opportunity for social cohesion between believers of the same denomination.

In terms of interdenominational ecumenical endeavours, a wider interdenominational ecumenical dialogue between African Pentecostals should also receive attention, although the difficulty of such an enterprise should be conceded given the wide diversity of Pentecostal groups and churches existing in Africa. Plüss (2003:12) thinks that the experience of being filled with the Holy Spirit can serve as a common theological notion even though it is played out in diversity. The experience of diversity is then a decisive factor in promoting Christian cooperation and ecumenical discussion. What joins Pentecostals is their shared primitivist and restorationist notion of the unique intervention of the Spirit despite internal disagreements and diverse institutionalisation.

Ecumenical relations should also be built on local level with historical main-line churches where a charismatic renewal originated and that led to Pentecostalisation of the churches involved as well as with neo-Pentecostalist groups that are exercising a great influence on the current church scene.

Another opportunity exists for Pentecostals to engage in ecumenical dialogue with African Indigenous Churches, many of whom originated from classical Pentecostal circles (Nel 2005), although their parted ways historically excluded any cooperation. The sentiment prevailing in a new democratic South Africa allows for such a dialogue to take place.

The aim of such ecumenical conversations should not primarily be to strive for doctrinal agreement or organisational unity. That would effectively undermine the success of such endeavours. It should rather look for mutual understanding and communication by undermining the stereotypes of each other that determined attitudes in the past and undermined ecumenical efforts so that participants may agree to disagree about certain matters that function at the periphery of the Christian faith. ${ }^{23}$ The different dialogues, as developed above, should each develop its own agendas. What is important is that ample opportunity be created for personal encounters between believers - if possible, also on the level of parishioners and the fostering of relationships. In this way the church will perform a prophetic function (Clifton 2012:592) and church unity will be served, congregations will start cooperating across boundaries, the impact of the local church will be enhanced, local socioeconomic and sociocultural concerns about social justice and historical inequalities will be addressed with, as its goal, the establishment of just and sustainable communities (Robra 2016:249). Furthermore, Pentecostalism will present the most cogent force in the globalisation of Christianity, in the words of Quayesi-Amakye (2014:255).

23.For example, the bilateral dialogue between Pentecostalism and the Roman Catholic Church stated explicitly that their 'goal is not structural unity, but rather the fostering of ... respect and mutual understanding' (Evangelization, proselytism, and common witness 1999:11) 
The movement's ecumenical successes would change not only its image with its partners, but also its own identity, because it will expose it to a global theological agenda that is multi-layered and diverse, going beyond Pentecostals' traditional interest in issues such as pneumatology, Spirit baptism, the charismata, and especially, glossolalia, faith healing and sanctification (Vondey 2013:9-27). For instance, Volf (1991:38-39) argues that Pentecostals' nearly exclusivist emphasis on tongues and prophecy should be enhanced by a broader perspective that the Spirit's presence enables all Christian activity to be charismatic, because extraordinary gifts are only one facet of the Spirit's work. Christian life, as such, should be transformed into a gift from the Spirit, emphasising the Spirit's empowerment for living the Christian life and fulfilling a personal calling. The charisms' relational orientation is not merely for personal benefit, but also intended to serve others (Volf 1991:113-114).

What ecumenical involvement requires from participants is that they should assess the potential and the gifts within their own tradition that can be employed toward Christian Unity; ${ }^{24}$ that they should face the challenges and impediments that ecumenical endeavours may contain; that they respect fellow-believers from other traditions (Albrecht 2017b:4); that they respect different realisations of spirituality, associated with culture and language; and that they should be able to discern and understand the other's spirituality. Albrecht (2017b:7) suggests that ecumenical endeavours call believers to learn the language of the other - a task that requires one also to learn and respect another's culture.

\section{Synthesis}

The early Pentecostal movement was driven by optimism about the ecumenical potential of Spirit baptism that did not realise when main-line churches rejected charismatic experience as valid. On national and international level, the movement has made room for ecumenical pragmatism. However, to realise the dream of its founders for an ecumenical impulse, it is proposed that the Pentecostal movement should grow to new forms of engagement, starting at the grass roots level and extending to the level of national and international bodies of organisation of churches. The opportunity should be created for personal, communal, institutional and multiracial participation that addresses local socioeconomic and sociocultural concerns. In this way, Pentecostals will become a positive force in a global context. Because the movement's distinctiveness is synonymous with its ecumenical identity as defined by its early leaders, making the ecumenical impulse an important part of Pentecostal DNA, Pentecostals should strive to sharpen their ecumenical focus and produce new and fruitful forms of dialogue on all levels. In supporting the ecumenical movement, Pentecostalism is capable of performing a prophetic function (Clifton 2012:592) despite the competition and 'partisan

24. Hocken (1987:118-121) remarks perceptively that there should never arise the need for apologising about one's own tradition or one's rootedness in that tradition, but on-going theological and doctrinal differences should be dealt with in the context of mutual recognition in a basic faith in Christ. rancour' that too often distort Pentecostal culture and the culture of churches in general.

\section{Acknowledgements Competing interests}

The author declares that he has no financial or personal relationships which may have inappropriately influenced him in writing this article.

\section{References}

Albrecht, D.E., 2017a, 'Pentecostal spirituality: Ecumenical potential and challenge. Part 1: Characteristic qualities of Pentecostal spirituality', Cyberjournal for Pentecostal-charismatic research, pp. 1-35, viewed 20 October 2017, from http:// www.pctii.org/cyberj/cyberj2/albrecht.html

Albrecht, D.E., 2017b, 'Pentecostal spirituality: Ecumenical potential and challenge. Part 2: Ecumenism and Pentecostal spirituality', Cyberjournal for Pentecostalcharismatic research, pp. 1-12, viewed 20 October 2017, from http://www.pctii. org/cyberj/cyberj2/albrecht.html

Anderson, A., 2005, 'Revising Pentecostal history in global perspective', in A. Anderson \& E. Tang (eds.), Asian and Pentecostal: The charismatic face of Christianity in Asia, pp. 147-173, Regnum, Oxford, UK. (Asian Journal of Pentecostal Studies Series 3).

Blumhofer, E.W., 1993, Restoring the faith: The Assemblies of God, Pentecostalism, and American culture, University of Illinois Press, Champaign, IL.

Brunner, E., 1953, The misunderstanding of the church, Lutterworth, London.

Burger, I. \& Nel, M., 2008, The fire falls in Africa: A history of the Apostolic Faith Mission of South Africa, Christelike Uitgewers Maatskappy, Vereeniging.

Burgess, S.M. (ed.), 2011, Christian peoples of the Spirit: A documentary history of Pentecostal spirituality from the early church to the present, New York University Press, New York.

Clifton, S., 2012, 'Ecumenism from the bottom up: A Pentecostal perspective', Journal of Ecumenical Studies 47(4), 576-592.

Conway, L.M., 1917, 'United we stand, divided we fall', Weekly Evangel, 14 April, p. 5.

Daniels, D., 1999, 'Everyone bids you welcome: A multicultural approach to North American Pentecostalism', in M. Dempster, B. Klaus \& D. Petersen (eds.), Globalization of Pentecostalism, pp. 222-252, Regnum, Irvine, CA.

Dayton, D.W., 1987, Theological roots of Pentecostalism, Hendrickson, Peabody, MA.

Dodson, J.D., 2011, 'Gifted for change: The evolving vision for tongues, prophecy, and other charisms in American Pentecostal churches', Studies in World Christianity 17(1), 50-71. https://doi.org/10.3366/swc.2011.0005

Evangelization, proselytism, and common witness, 1999, 'The report from the fourth phase of the International Dialogue (1990-1997) between the Roman Catholic Church and some classical Pentecostal churches and leaders', Pneuma 21 , 11-51.

Faupel, D.W., 1996, The everlasting gospel: The significance of eschatology in the development of Pentecostal thought, Sheffield Academic Press, Sheffield.

Francis, 2013, Apostolic exhortation evangelii gaudium of the holy father Francis to the bishops, clergy, consecrated persons and the lay faithful on the proclamation of the gospel in today's world, Vatican Press, Rome.

Frodsham, S.H., 1971, 'Disfellowshipped!', Pentecostal Evangel, 18 August, p. 7.

Green, C.E., 2011, "The body of Christ, the spirit of communion": Re-visioning Pentecostal ecclesiology in conversation with Robert Jenson', Journal of Pentecostal Theology 20, 15-26. https://doi.org/10.1163/174552511X554546

Hinson, E.G. (ed.), 1993, Spirituality in ecumenical perspective, Westminster/John Knox, Louisville, KY.

Hocken, P., 1987, One Lord, One Spirit, One body: The ecumenical grace of the charismatic movement, Paternoster, Exeter.

Hollenweger, W.J., 1997, Pentecostalism: Origins and developments worldwide, Hendrickson, Peabody, MA.

Hollenweger, W.J., 2000, 'Two extraordinary Pentecostal ecumenists: The letters of Donald Gee and David du Plessis', Ecumenical Review 52(3), 391-402. https://doi. org/10.1111/j.1758-6623.2000.tb00046.x

Jacobsen, D., 2010, 'The ambivalent ecumenical impulses in early Pentecostal theology in North America', in W. Vondey (ed.), Pentecostalism and Christian unity: Ecumenical documents and critical assessments, pp. 3-19, Pickwick, Eugene, OR.

Kalu, O., 2008, African Pentecostalism: An introduction, Oxford University Press, Oxford, UK.

Kärkkäinen, V.-M., 2000, 'Anonymous ecumenists? Pentecostals and the struggle for Christian unity', Journal of Ecumenical Studies 37(1), 13-27.

Kärkkäinen, V.-M., 2007, 'The church as the fellowship of persons', PentecoStudies $6(1), 1-15$.

Lancaster, S.J., 1926, 'Good news hall', Good News 17, 10-13.

Lapoorta, J.L., s.a., Unity or division? The unity struggle of the black churches within the Apostolic Faith Mission of South Africa, Revelation Desk, Kuils River. 
Lederle, H.I., 2010, Word and Spirit: The future of the Pentecostal and charismatic movements in the twenty-first century, Word \& Spirit, Tulsa.

Lewis, P.W., 2001, 'Reflections of a hundred years of Pentecostal theology', paper presented at the 9th Annual William Menzies Lectureship, Asia Pacific Theologica Seminary, Baguio, Philippines, 12th January. http://www.apts.edu/index.cfm? menuid=27\& parentid=14; accessed 2018-04-06

Lewis, P.W., 2016, 'Reflections of a hundred years of Pentecostal theology', Cyberjournal for Pentecostal-charismatic research pp. 1-25, paper originally presented at the 9th Annual William.

Macchia, F.D., 2003, “I belong to Christ": A Pentecostal reflection on Paul's passion fo unity', Pneuma 25(1), 1-6. https://doi.org/10.1163/157007403765694385

Macchia, F.D., 2006, Baptized in the Spirit: A global Pentecostal theology, Zondervan, Grand Rapids, MI.

Mahlobo, M.G., 2014, 'General Secretary's report for the 2014 General Business Meeting of the Apostolic Faith Mission of South Africa', General Business Meeting 2014 Agenda, pp. 112-120.

Mahlobo, M.G., 2016, 'General Secretary's report for the 2016 General Business Meeting of the Apostolic Faith Mission of South Africa', General Business Meeting 2016 Agenda, pp. 12-27.

Martin, D., 2002, Pentecostalism: The world their parish, Blackwell, Oxford, UK.

McDonnell, K., 1972, The baptism in the Holy Spirit as an ecumenical problem, Charismatic Renewal Services, South Bend, IN.

McDonnell, K., 1978, The charismatic renewal and ecumenism, Paulist, New York.

McDonnell, K., 1980, Presence, power, praise: Documents on the charismatic renewal, 3 vols., Liturgical, Collegeville, MN.

Menzies Lectureship in January, 2001 at Asia Pacific Theological Seminary in Baguio Philippines, viewed 31 January 2016, from http://www.pctii.org/cyberj/cyberj12/ lewis.htm\#_ftn1

Nel, M., 2005, 'P L le Roux, Dutch Reformed missionary, Zionist preacher and leader of the Apostolic Faith Mission of South Africa, and the origin of some of the African Independent Churches in Southern Africa', Ned Geref Teologiese Tydskrif 46(1-2), 200-208.

Nel, M., 2016, 'Pentecostalism and the early church: On living distinctively from the world', Journal of Theology for Southern Africa 153, 141-159.

Nel, M., 2017, 'The Pentecostal movement's view of the continuity of tongues in Acts and 1 Corinthians', In die Skriflig 51(1), a2198. https://doi.org/10.4102/ids.v51i1.2198

Nichol, J.T., 1966, Pentecostalism, Harper \& Row, New York.

Noel, B.T., 2010, Pentecostal and postmodern hermeneutics: Comparisons and contemporary impact, WIPF \& STOCK, Eugene, OR.

Parham, C.F., 1902, Kol KareBemidbar: A voice crying in the wilderness, Robert L. Parham, Baxter Springs, KS.

Plüss, J.-D., 2003, 'Religious experience in worship: A Pentecostal perspective', PentecoStudies 2(1), 1-21.

Poloma, M.M., 1989, The Assemblies of God at the crossroads: Charisma and institutional dilemmas, University of Tennessee Press, Knoxville, TN.

Quayesi-Amakye, J., 2014, 'Coping with evil in Ghanaian Pentecostalism', Exchange 43, 254-272. https://doi.org/10.1163/1572543X-1234l327

Railey, J.H. \& Aker, B.C. (eds.), 2007, 'Theological foundations', in S. Horton (ed.), Systematic theology, rev. edn, pp. 40-60, Logion, Springfield, IL.

Rance, D.L., 2009, 'Fulfilling the apostolic mandate in apostolic power: Apostolic praxis: Driven by the Spirit or by the wind and the waves?', Encounter: Journal for Pentecostal Ministry 6, 1-14.

Robeck, C.M., 1986, 'Pentecostals and the apostolic faith: Implications for ecumenism' Pneuma: The Journal of the Society for Pentecostal Studies 9(1), 61-84. https:// doi.org/10.1163/157007487X00065

Robeck, C.M., 1991, 'Pentecostals and ecumenism: An expanding frontier', Conference on Pentecostal and charismatic research in Europe, Kappel, Switzerland, 5th July 1991, pp. 1-17.
Robeck, C.M., 1993, 'Taking stock of Pentecostalism: The personal reflections of a retiring editor', Pneuma 15(1), 35-60. https://doi.org/10.1163/157007493X00040

Robeck, C.M., 1994, 'Discerning the Spirit in the life of the church', in W. Barr \& R. Yocum (eds.), The church in the movement of the Spirit, pp. 29-49, Eerdmans, Grand Rapids, MI.

Robeck, C.M., 1995, 'A Pentecostal looks at the World Council of Churches', The Ecumenical Review 47(1), 60-69. https://doi.org/10.1111/j.1758-6623.1995. tb03681.x

Robeck, C.M., 1996, 'Mission and the issue of proselytism', International Bulletin of Missionary Research 20(1), 2-8. https://doi.org/10.1177/239693939602000101

Robeck, C.M., 1997, 'The Assemblies of God and ecumenical cooperation: 1920-1965', in W. Ma \& R. Menzies (eds.), Pentecostalism in three contexts:
Essays presented to William W. Menzies on the occasion of his sixty-fifth birthday, Essays presented to William W. Menzies on the occasion of his sixty-fifth birthday,
pp. 107-150, Sheffield Academic Press, Sheffield. (Journal of Pentecostal Theology Suppl. Series).

Robeck, C.M., 2004, 'Pentecostals and Christian unity: Facing the challenge', Pneuma 26, 308-309. https://doi.org/10.1163/157007404776110983

Robeck, C.M. \& Sandidge, J.L., 1990, 'The ecclesiology of koinonia and baptism: A Pentecostal perspective', Journal of Ecumenical Studies 27(3), 504-534.

Robinson, M., 1992, 'David du Plessis: A promise fulfilled', in J.A.B. Jongeneel (ed.), Pentecost, mission and ecumenism: Essays on intellectual theology: Festschrift in honour of Professor Walter J. Hollenweger, pp. 143-155, Peter Lang, Frankfurt.

Robra, M., 2016, 'Moving in the Spirit: Called to transforming discipleship' International Review of Missions 105(2), 243-256. https://doi.org/10.1111/ irom. 12147

Seymour, W., 1906, 'The Apostolic Faith movement', Apostolic Faith 1(1), 2.

Slosser, B., 1977, A man called Mr Pentecost: The story of David du Plessis, Logos International, Plainfield, NJ.

Stephenson, C.A., 2009, 'Pentecostal theology according to the theologians: An introduction to the theological methods of Pentecostal systematic theologians', unpublished PhD dissertation, Marquette University, Milwaukee.

Stephenson, C.A., 2013, 'Proclaiming the mystery of faith together: Toward greater common witness between Pentecostals and Roman Catholics on the Lord's Supper', Journal of Ecumenical Studies 48(1), 85-96.

Synan, V., 1997, The holiness-Pentecostal tradition: Charismatic movements in the twentieth century, 2nd edn., Eerdmans, Grand Rapids, MI.

Van Beek, H., 2006, 'Pentecostals-ecumenicals dialogue', in A. Droogers, C. van der Laan \& W. van Laar (eds.), Fruitful in this land: Pluralism, dialogue and healing in migrant Pentecostalism, pp. 81-92, WCC, Geneva.

Venter, J.J., 2008, 'Die Heilige Gees as bewerker van eenheid in die liggaam van Christus', PhD-proefskrif, Universiteit van die Vrystaat.

Volf, M., 1991, Work in the Spirit: Toward a theology of work, Oxford University Press, New York.

Vondey, W., 2001, 'Presuppositions for Pentecostal engagement in ecumenical dialogue', Exchange: Journal for Missiological and Ecumenical Research 30(4), 344-358. https://doi.org/10.1163/157254301X00228

Vondey, W., 2010, Beyond Pentecostalism: The crisis of global Christianity and the renewal of the theological agenda, pp. 155-159, Eerdmans, Grand Rapids, MI.

Vondey, W., 2011, 'The denominations in classical and global Pentecostal ecclesiology: A historical and theological contribution', in P.M. Collins \& B. Ensign-George (eds.) Denomination: Assessing an ecclesiological category, pp. 100-116, Continuum, New York. (Ecclesiological investigations 11).

Vondey, W., 2013, Pentecostalism: A guide for the perplexed, Bloomsbury, London.

Vondey, W., 2014, 'Pentecostalism and ecumenism', in C.M. Robeck \& A. Yong (eds.), The Cambridge companion to Pentecostalism, pp. 273-293, Cambridge University Press, New York.

Wacker, G., 1984, 'The functions of faith in primitive Pentecostalism', Harvard Theological Review 77(3-4), 353-375. https://doi.org/10.1017/\$0017816000 027280 